High jugular bulb in a cohort of patients with definite Ménière's disease

Dear Sirs,

We read the article by Redfern et al., ${ }^{1}$ entitled 'High jugular bulb in a cohort of patients with definite Ménière's disease', with great interest. This study supports the findings of the recent study by Park et al., ${ }^{2}$ which focused on the same topic using a different methodology. Both studies show an increase of jugular bulb abnormalities in Ménière's disease compared with the asymptomatic side $^{1}$ or a control group. ${ }^{2}$ This approach provides a new means to understand Ménière's disease physiopathology. In addition, the findings have clinical consequences that are worth knowing by the surgeon. Indeed, as explained by Redfern et al., some Ménière's symptoms have already been cured by surgical ${ }^{3,4}$ or endovascular ${ }^{5}$ treatments of jugular bulb abnormalities. Nevertheless, jugular bulb abnormalities - even with inner-ear or aqueduct dehiscences - are asymptomatic in nearly half of the cases. ${ }^{6}$

It is thus important to differentiate between those jugular bulb abnormalities that are responsible for the Ménière'slike syndromes and those which are fortuitous associations. To do this, the surgeon must look for four clues which indicate that a jugular bulb abnormality is symptomatic: (1) vertigo may be induced by high venous pressure (coughing, Valsalva manoeuvre $)^{5}$ or sound (i.e. Tullio phenomenon); (2) tinnitus may be pulsatile (in 33 per cent of cases); ${ }^{5,7}$ (3) a nystagmus may be identified when performing vestibular nystagmography during the Valsalva manoeuvre, ${ }^{5}$ and (4) vestibular evoked myogenic potential may show a threshold below $70 \mathrm{~dB}$ (in 63 per cent of cases). ${ }^{5,6}$ These low thresholds (as in superior canal dehiscence) result from a third window phenomenon; ${ }^{8}$ they differ from typical Ménière's disease, which exhibits no vestibular evoked myogenic potential responses despite a stimulus of $100 \mathrm{~dB}$ (in 54 per cent of cases). ${ }^{9}$

In conclusion, this study by Redfern et al. reminds us that Ménière's disease is, by definition, idiopathic, which means its physiopathology is not completely understood. It is likely that different mechanisms are hidden within the 'idiopathic' element, including symptomatic dehiscence induced by jugular bulb abnormalities. It is therefore important that screening for symptomatic jugular bulb abnormalities is conducted and a specific treatment proposed.

\section{HITIER $^{1,2,3}$}

V ROGER ${ }^{1}$

S MOREAU ${ }^{1,2}$

V PATRON $^{1}$

${ }^{1}$ Department of Otolaryngology - Head and Neck Surgery, Centre Hospitalier Universitaire de Caen, France

${ }^{2}$ Department of Anatomy, University of Caen Lower Normandy ('UNICAEN'), France

${ }^{3} \mathrm{U} 1075$ COMETE, Institut national de la santé et de la recherche médicale ('INSERM'), Caen, France

\section{References}

1 Redfern RE, Brown M, Benson AG. High jugular bulb in a cohort of patients with definite Ménière's disease. J Laryngol Otol 2014; 128:759-64

2 Park JJ, Shen A, Keil S, Kuhl C, Westhofen M. Jugular bulb abnormalities in patients with Meniere's disease using high-resolution computed tomography. Eur Arch Otorhinolaryngol 2014. Epub 2014 Mar 20

3 Couloigner V, Grayeli AB, Bouccara D, Julien N, Sterkers O. Surgical treatment of the high jugular bulb in patients with Ménière's disease and pulsatile tinnitus. Eur Arch Otorhinolaryngol 1999;256:224-9

4 Kieran SM, Meyer TA. Cochlear Ménière's disease in association with a high jugular bulb. Otol Neurotol 2014. Epub 2014 Aug 12

5 Hitier M, Barbier C, Marie-Aude T, Moreau S, Courtheoux P, Patron V. New treatment of vertigo caused by jugular bulb abnormalities. Surg Innov 2013;21:365-71

6 Friedmann DR, Eubig J, Winata LS, Pramanik BK, Merchant SN, Lalwani AK. A clinical and histopathologic study of jugular bulb abnormalities. Arch Otolaryngol Head Neck Surg 2012;138: 66-71

7 Friedmann DR, Le BT, Pramanik BK, Lalwani AK. Clinical spectrum of patients with erosion of the inner ear by jugular bulb abnormalities. Laryngoscope 2010;120:365-72

8 Minor LB. Clinical manifestations of superior semicircular canal dehiscence. Laryngoscope 2005;115:1717-27

9 de Waele C, Tran Ba Huy P, Diard JP, Freyss G, Vidal PP. Saccular dysfunction in Ménière's patients. A vestibular-evoked myogenic potential study. Ann N Y Acad Sci 1999;871:392-7 